\title{
TWO NOTES ON THE COPTIC THEOTOKIAS
}

\section{Note on a pun in a Coptic Theotokia of Sunday}

The Copts love playing on words and making puns, ${ }^{1}$ they are in the same mentality as most of the oriental peoples. ${ }^{2}$ In a previous article, while studying theotokias, ${ }^{3}$ I highlighted a pun, based on the name of Jesus and the Ten commandments. ${ }^{4}$ I deduced that the theotokias were written in Coptic.

While re-reading the text, I came across another pun in the Sunday theotokia.

Here is the text

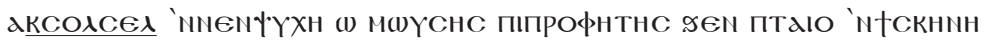

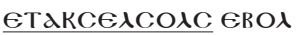

The translation given by the editor of the Arabic text and hence the recent English text is:

$$
\text { زينت انفسنا يا مو سى النبي بكر امة القبة التي زينتها }
$$

You adorned our souls, o Moses the prophet with the honour of the tent that you adorned

Brogi, in his Italian translation, rendered this sentence thus:

(1) Y. N. Youssef, Un jeu de mots dans le rituel de la consécration des icônes, Göttinger Miszellen 142 (1994) 109-111; Boyaval, Jeu de mots dans un distique Chrétien d'Egypte? Compte-Rendu de l'Insititut de Papyrologie et de l'Egyptologie de Lille 23 (2003) 95-96.

(2) Y. N. Youssef, La genèse de la légende sur le roi Dioclétien, BSA 28 (1986-1989) 107-110.

(3) Y. N. Youssef, Severus of Antioch in the Coptic Theotokia, in: B. NeIL, G. Dunn, L. Cross (eds.), Prayer and Spirituality in the Early Church: Liturgy and life, vol. 3 (Sydney 2003) 93-108; IDEM, The Coptic Marian homilies of Severus of Antioch, BSAC 43 (2004) 127-140.

(4) Y. N. Youssef, Une relecture des Théotokies Coptes, BSA 36 (1997) 153-170.

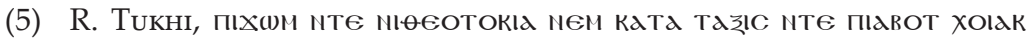
[The book of the Theotokias and according to the rite of the month of Kihak] (Rome,

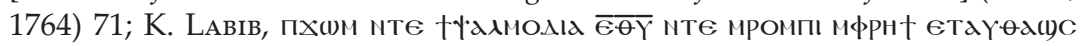


“Consolasti le nostre anime, oprefeta Mosè, onorando il tabernacolo che tu avevi ornato." 6

The author of this text played on the double meaning of the verb colces "adorn"7 and "Comfort, encourage."

The Biblical and liturgical texts attest both meanings. These meanings were known even in its late stage. It is attested in the Al-Sullam al-Muqaffa wa-al-Dhahab al-Musaffa. rhymic scala of al-Mu'taman ${ }^{9} \mathrm{Ibn}$ al-Assal ${ }^{10}$

In this article we will give some examples of the usage of these words.

\section{Adorn}

\section{A - In the Bible}

This meaning occurs in Gospel Bohairic version of Matthew 23:9 (Bohairic)

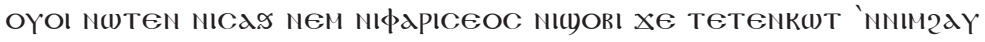

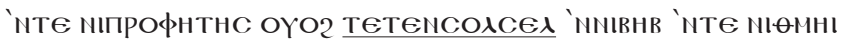

Woe unto you, scribes and Pharisees, hypocrites! because ye build the tombs of the prophets, and adorn the sepulchers of the righteous,

Matthew 25:7 (Bohairic)

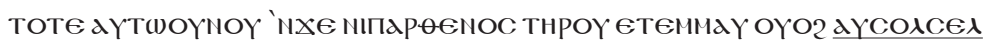

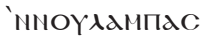

Then all those virgins arose, and adorned their lamps.

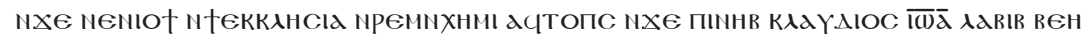

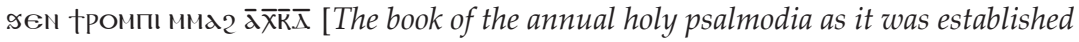
by the fathers of the fathers of the Coptic Church, printed by Mr Klaudios John Labib Bey in the year 1624] (Cairo, 1908) 91; MinA AL-BAramousi, †үaגmosid н†ромп €өоүав [The Holy Annual Psalmodia] (Alexandria, 1908) 138.

(6) M. Brogi, La santa salmodia annuale della chiesa Copta (Cairo, 1962) (Studia Orientalia Christiana Aegyptiaca) 42.

(7) W. E. Crum, A Coptic dictionary (Oxford, 1937) 331b-332a.

(8) Ibid., 332a-332b.

(9) G. Graf, Geschichte der Christlichen Arabischen Literatur (Città del Vaticano, 1947) (Studi e Testi, 133) 345, 347, 383, 404. cf. A. WAdi, Dirasa 'an alMu'taman Ibn al-'Assal wa-kitabihi "Magmu' usul al-din" wa-tahqiqihi (italian title Studio su ...), SOC.M 5 (Cairo-Jerusalem: The Franciscan Centre of Christian Oriental Studies, 1997) 188 \& 86, n. 24.

(10) A. Kircher, Lingua Aegyptiaca Restituta (Rome, 1648) 359-360. 


\section{Luke 21: 5 (Bohairic)}

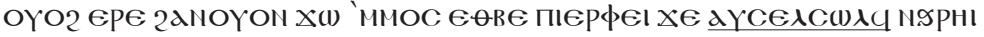

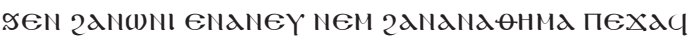

And as some spoke of the temple, how it was adorned with goodly stones and gifts, he said,

\section{Timothy 2:9 (Bohairic)}

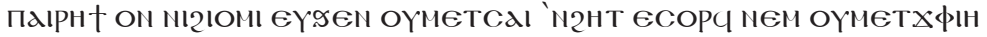

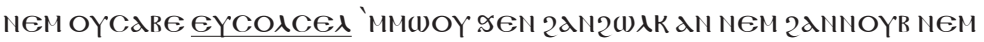

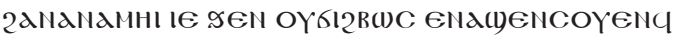

In like manner also, women adorn themselves in modest apparel, with shamefacedness and sobriety; not with broided hair, or gold, or pearls, or costly array;

\section{Peter 3:3-5 (Bohairic)}

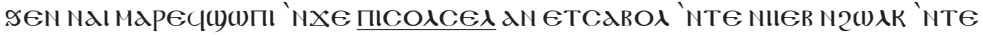

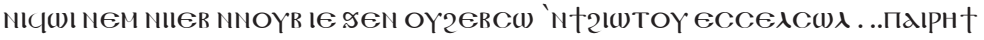

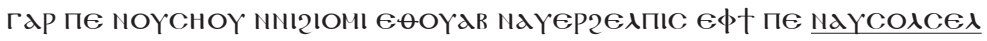

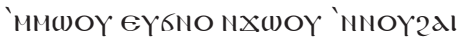

Whose adorning let it not be that outward [adorning] of plaiting the hair, and of wearing of gold, or of putting on of apparel; ... For after this manner in the old time the holy women also, who trusted in God, adorned themselves, being in subjection unto their own husbands:

\section{B - In Liturgical books}

In the rite of the marriage according to the book of the Lamp of the Darkness for the Elucidation of Service compiled by Shams al-Ri'asah Abu al-Barakat known as Ibn Kabar, ${ }^{11}$ in the Chapter XX, although this part has never been scholarly published ${ }^{12}$ mentions: $^{13}$

(11) On the work of Ibn Kabar, see Samir KHALIL, L'Encyclopédie liturgique d'Ibn Kabar †1324 et son apologie d'usages coptes, in : H.-J. Feulner, E. Velokovska, R. F. Taft (eds.), Crosswords of Cultures Studies in Liturgy and Patristics in Honor of Gabriele Winkler (Roma, 2000) 619-655.

(12) Only two popular editions one by Samuel bishop of Shibin al-Qanatir according to a manuscript copied by Shenoudah al-Baramusi copied on 1955 and the other edition done by Mina Foundation for publication in 1998. See A. WAdi, Abu al-Barakat Ibn Kabar, Misbah al-Zulmah, Studia Orientalia Christiana Collectanea 34 (2001) 243.

(13) Text is taken from Paris Arabe 203, fol. $\overline{\mathrm{P}} \overline{\mathrm{Z}}$ [221r] Cf. also A. AbDALLAH, L'ordinamento Liturgico di Gabriele V, 88 Patriarca Copti 1409-1427 (Cairo, 1962) 135. 


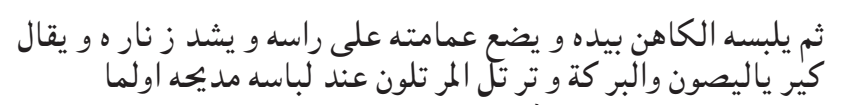

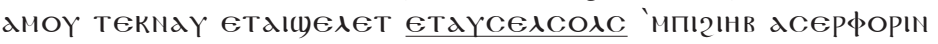

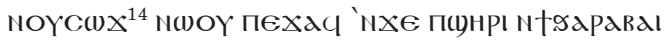

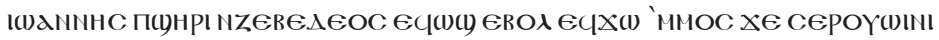

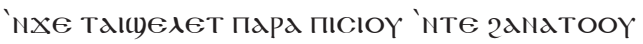

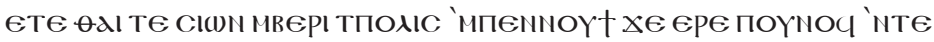
мнєөоүав тнроү (юп 'мярні 'мянте

"Come to see the bride who has been adorned for the lamb, ${ }^{15}$ she bore a great ${ }^{16}$ glory, said the son of Charabai

John the son of Zebedeus crying out and saying: "This bride was shinning more than the star of the morning

That is the new Sion, the city of our God, wherein is the joy of all saints."

A note in the margin adds, "This psali is dedicated to the Lady. It has been composed by a father from the monks of Abu Maqar from the cell of Kadran and his name occurs in the first letters of the beginning of each stanza."17

This hymn occurs in three manuscripts kept in Germany. ${ }^{18}$ The manuscripts could be dated by the twelfth/thirteenth century.

It is important to mention that this text is inspired from Apoc 21:9 while the word colces does not occur in both Sahidic and Bohairic version.

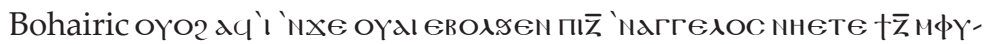

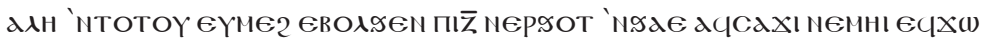

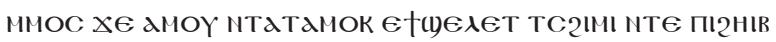

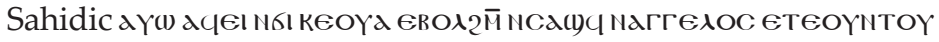

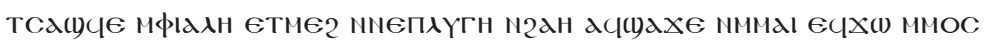

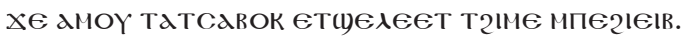

(14) Corrected over the line noymint. Abdallah read oy

(15) Rev. 21:9 the Coptic version is different.

(16) Translation according to the correction of the text of Ibn Kabar and Gabriel V

(17) The translation is given according to the edition of Mina Foundation, p. 183-184.

(18) L. SтӧRк, Koptische Handschriften 2, die Handschriften der Staats- und Universitätsbibliothek Hamburg, Teil 2, Die Handschriften aus Dair Anba Maqar (Stuttgart, 1995) (Verzeichnis der Orientalischen Handschriften in Deutschland, XXI.2) 273, 454; IDEM, Koptische Handschriften 4, die Handschriften der Staatsbibliothek zu Berlin, Teil 2, Teil 1 Liturgische Handschriften 1 (Stuttgart, 2002) (Verzeichnis der Orientalischen Handschriften in Deutschland, XXI.4) 35. 
And there came unto me one of the seven angels which had the seven vials full of the seven last plagues, and talked with me, saying, Come hither, I will show thee the bride, the Lamb's wife.

The rite of marriage (Crowning)

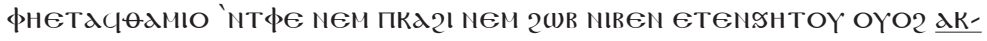

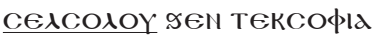

Who created heaven and earth and everything they are in them, and you adorned them with your wisdom. ${ }^{19}$

The rite of Baptism, the absolution of the woman for having a male boy:

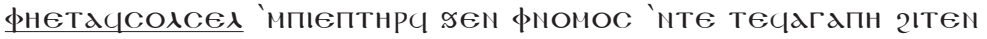
†окомома нте пєцдогос ммоногеннс 'м(унрі .

O Who adorned (comforted) the universe with the Law of Charity through the economy of His Word, the Only-Begotten Son... ${ }^{20}$

The liturgy of Baptism attributed to Severus of Antioch ${ }^{21}$ (which survived in Greek, Coptic and Syriac)

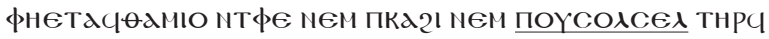

Who created heaven and earth and all their adornment. ${ }^{22}$

(19) Philotheus AL-Maqari, Barnaba AL-BARAmousi, حتاب رتبة الاكليل الجليل [The book of the rite of the glorious crowning according to the ordo of the Coptic Orthodox Church of the predication of Saint Mark] (Cairo, 1921) 32

كتاب المعمودية المقدسة Philotheus AL-MaqARI, Barnaba AL-BARAmousi, كائل [The book of the holy Baptism used in the churches of the predication of Saint Mark] (Cairo, 1921) 8.

(21) Sтӧвк, Koptische Handschriften 2..., 314. for an English translation cf. R. M. Wooley, Coptic Offices (London, 1930) (Translations of Christian Literature Series, III. Liturgbical Texts) 35-36. It is noteworthy that this prayer is not the same as the rite of Baptism attributed to Severus of Antioch in the Syriac Church cf. Murad Saliba BARsom, The Sacrament of the Holy Baptism according to the Ancient Rite of the Syrian Orthodox Church of Antioch (The Syrian Orthodox Church in the United States of America and Canada, 1974) 86-92. For the works of Severus concerning the Rite of Baptism cf. B. VARGHEsE, Les Onctions Baptismales dans la Tradition Syrienne (Louvain, 1989) (CSCO, 512) 170-180; O. H. E. Burmester, Baptismal Rite of the Coptic Church, BSAC 11 (1945) 37-39. But in the Syriac rite is attributed to James of Edessa.

(22) Philotheus AL-MaqARI, Barnaba AL-BARAmousi, ....كتاب المعمودية, 72. 


\section{In the book of Glorifications ${ }^{23}$}

A Doxology Adam for the Birth of the Virgin

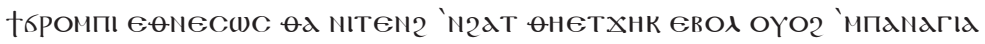

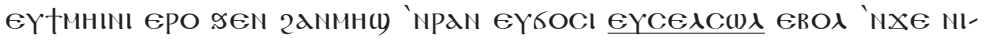

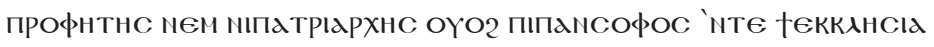

The beautiful dove, who has silver wings, the perfect and all-holy. The prophets and the patriarchs and the all-wise of the Church indicate about you with many names, extremely sublim and adorned (or comforting) ${ }^{24}$

A hymn for the entry of the Virgin to the temple:

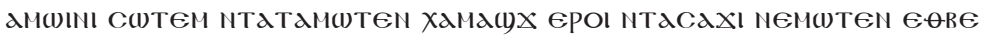

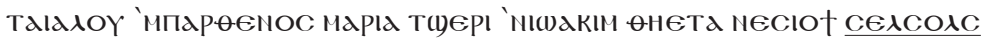

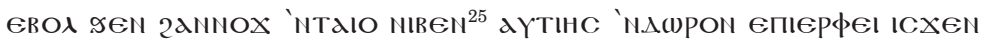
धсхн яен г 'мромп

Come, hear, in order that I inform you, listen so that I talk with you about this virgin girl Mary daughter of Joachim that her parents adorned her with great, all honours and presented as a gift to the temple since she was 3 years old ${ }^{26}$

A hymn for the dormition of the Virgin:

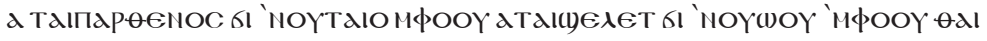

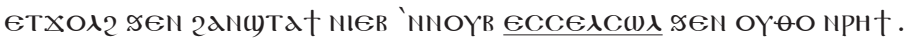

"This Virgin has, today attained honour. This bride has toaday attained glory, her gown is made of gold thread and is adorned with many things" 27

A hymn for the consecration fo the Church of the Virgin:

(23) for this book cf. Y. N. Youssef, Un témoin méconnu de la littérature copte, BSA 32 (1993), 139-147 ; IDEM, Une relecture des glorifications coptes, BSA 34 (1995) 77-83. Cf. also Yassa Abd AL-MAsin, Doxologies in the Coptic Church, edited Bohairic doxologies, BSA 6 (1940) 19-76, see p. 71.

(24) Attallah Arsenius al-Moharradi, пxwm nte mixin†woy $\bar{\epsilon} \bar{\theta}$

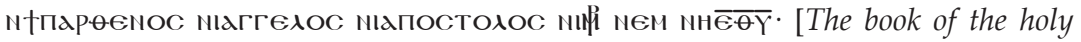
Glorifications for the Virgin, the angels, the apostles, the martyrs and the saints] (Cairo, 1972) 32.

(25) This text is not grammatically correct as the indefinite article should be omit before NIBEN

(26) Attallah, пх(мм nte mixin †woy..., 38-39.

(27) Ibid., 45. 


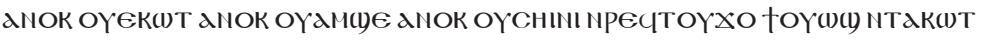

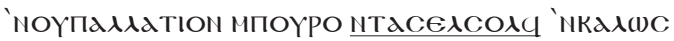

I am a builder, I am a carpenter, I am a healer physician, I wish to build a palace of the king and to well adorn it. ${ }^{28}$

For the Epiphany and the feast of John the Baptist adorn

'нөок пє псодсєл мпџдає

You are the adornment (consolation) of the desert. ${ }^{29}$

\section{In the book of the Psalmodia}

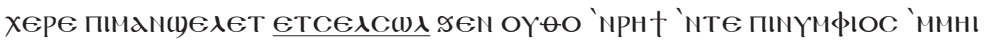
етас†нетрюм

Hail to the bridal chamber adorned in every way, for the true Bridegroom, who united with humanity. ${ }^{30}$

\section{Consolation, comfort}

This meaning occurs on the Gospels in the Sahidic versions only while in Bohairic there are different words:

\section{A - In the Bible}

\section{Matthew (Sahidic)}

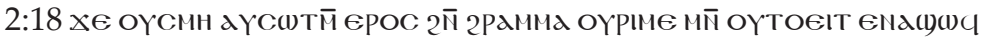

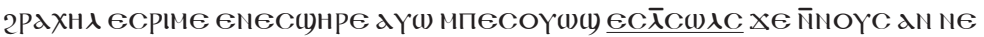

2:18 In Rama was there a voice heard, lamentation, and weeping, and great mourning, Rachel weeping [for] her children, and would not be comforted, because they are not.

Luke 16: 19 (Bohairic)

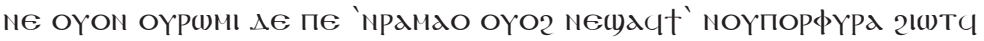

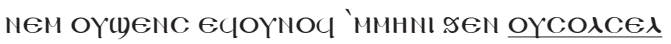

There was a certain rich man, which was clothed in purple and fine linen, and fared sumptuously every day:

Luke (Sahidic)

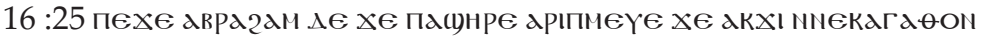

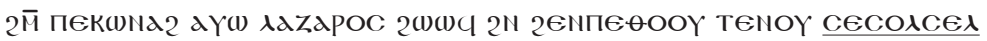

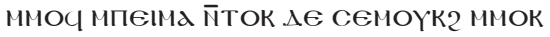

(28) Attallah, пхшм nte nixin†wOY..., 59

(29) Ibid., 75.

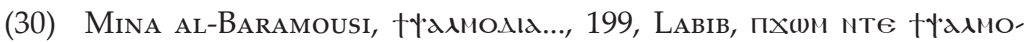
Ald..., 135. 
16:25 But Abraham said, Son, remember that thou in your lifetime received your good things, and likewise Lazarus evil things: but now he is comforted, and thou art tormented.

\section{John (Sahidic)}

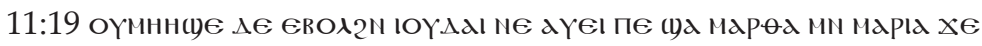
еүселс(1)八оY єтвє пеүсон

11:19 And many of the Jews came to Martha and Mary, to comfort them concerning their brother.

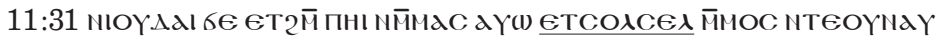

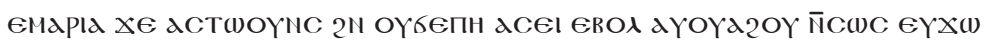

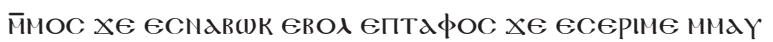

11:31 The Jews then which were with her in the house, and comforted her, when they saw Mary, that she rose up hastily and went out, followed her, saying, She goes unto the grave to weep there.

\section{In the Psalmodia}

The same word is used to give the meaning of Consolation in the doxology for the Virgin:

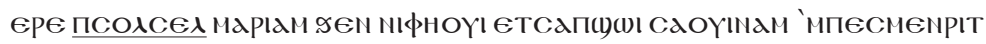

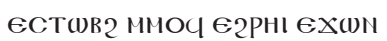

The consolation of Mary, in upper Heavens at the right of her Beloved, is to pray Him for our sake. ${ }^{31}$

And the second doxology for the Virgin for the Month of Kihak ${ }^{32}$

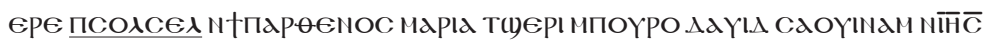
$\Pi \overline{\bar{X}} \overline{\mathrm{C}}$ пунні мф† пाмємріт

The consolation of the Virgin, Mary the daughter of King David, at the right of Jesus Christ the Beloved Son of God. ${ }^{33}$

Yassa Abd-Al-Masih translated the word colces in both stanzas as "adornment", 34 while the use of the other meaning suits better the context.

(31) Brogi, La santa salmodia..., 89 (ornamento); Mina AL-Baramousi,

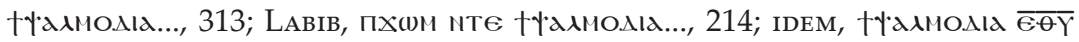
нте підвот ХоІак [The book of the holy Psalmodia of the month of Kihak] (Cairo, 1911-1922) 331-332.

(32) Y. N. Youssef, A doxology for the month of Kihak, Journal of Coptic Studies 8 (2006) 79-85.

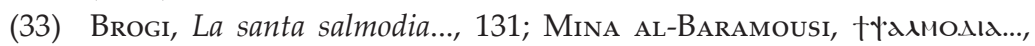

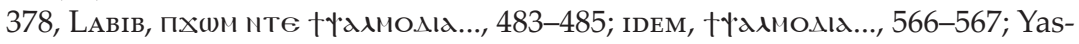
sa Abd AL-Masin, Doxologies..., 19-76.

(34) Yassa Abd AL-Masin, Doxologies..., 20, 35. 
The daily psalis of Monday:

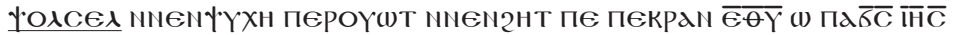

The consolation of our souls and the joy of our hearts is Your holy name o my Lord Jesus ${ }^{35}$

Il tua Santo Nome. O moi ignore Gesù è consolazione delle nostre anime e gioia dei nostri cuori ${ }^{36}$

The doxology of Saint Macarius the Great:

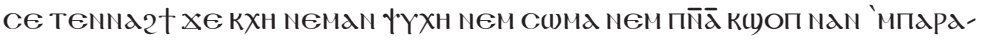

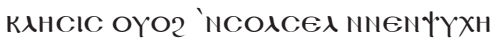

Yes we believe that you are with us, soul, body and spirit. You became for us, a consolation and comfort to our souls. ${ }^{37}$

$\mathrm{Si}$ crediamo che sei con noi, anima e corpo e spirite, e sei per no un consolatore ed un consolatore delle nostre anime ${ }^{38}$

A doxology for Damianah

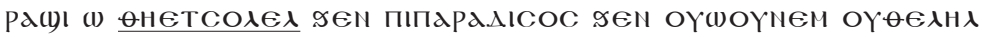
Nd2PEn $\Pi \bar{x} \overline{\mathrm{C}}$

Be happy o that who is adorned (conforted) in the Paradise with glory and joy in front of Christ. ${ }^{39}$

\section{B - In the psalis}

The psalis in are in general from late date. Some of them are composed by Nicodemus (XVIII century). They are inspired by other liturgical texts.

Psali Adam for Nairouz This psali is from the last letter to the first. The stanza here is inspired by the daily psali of Monday:

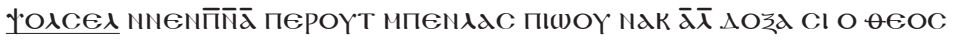

The consolation of our spirits and the joyness of our tongues,

Glory be to You Alleluia, Glory be to You, o God ${ }^{40}$

The psali of Saint Mark inspired by the Theotokia of Sunday:

(35) LАвІв, пхшм нте †үалмолıа..., 110

(36) Brogi, La santa salmodia..., 48.

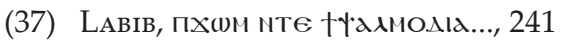

(38) Brogi, †үadmo.sid..., 104

(39) Attallah, пхшм nте mixin †шоү..., 226.

(40) Philotheus AL-Maqari, Mikhail Girgis, كتاب الابصاليات والواطس والإدام [The book of the Psalis and Turhurat, Batos and Adam used in the churches of the predication of Saint Mark] (Cairo, 1913) 11. 


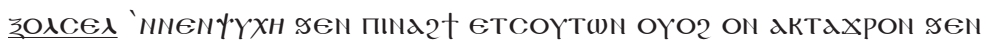
пекеүаггеліон

You console our souls with the right faith and also you established us in your Gospel ${ }^{41}$

Psali Adam for the Virgin Mary for the consecration of the sanctuary of the monastery of al-Muharraq:

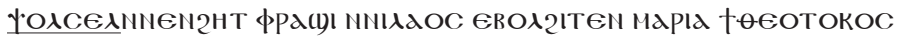

The consolation of our heart, the happyness of the peoples through Mary the God-Bearer ${ }^{42}$

Psali Batos of saint George attributed to Nicodemus

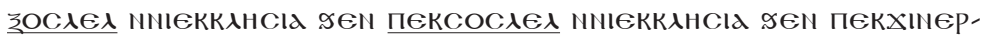

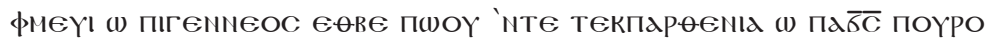
гешргіOC

You console the churches through your consolation of the churches in your commemoration, o brave because of the glory of your chastety, o my lord king George ${ }^{43}$

Psali Adam for Saint George

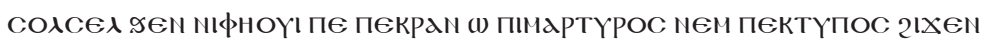

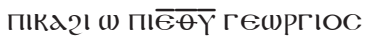

You are (a) Consolation (adornment) in heavens, o Martyr and your example (type) [is] on earth o saint George. ${ }^{44}$

Psali Adam for Saint Mercurius

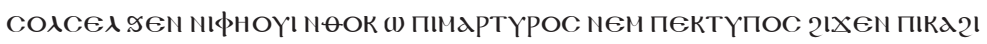
(1) фне $\bar{\epsilon} \bar{\theta}$ меркоүріос

You are (a) Consolation (adornment) in heavens, o Martyr and your example (type) [is] on earth, o saint Mercurius

Psali for the consecration of the Church of Abba Shenoudi

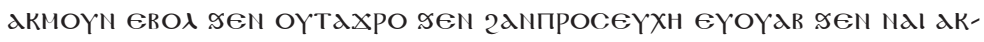

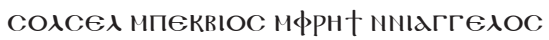

You remain firmly, in holy prayers, therefore you console (adorn) your life like the angels. ${ }^{45}$

(41) Philotheus aL-Maqari, Mikhail Girgis, ...المستعمل في كنائس, 122.

(42) Ibid., 134.

(43) Ibid., 138.

(44) Ibid., 145.

(45) De Lacy O'Leary, The Difnar (Antiphonarium) of the Coptic Church (London, 1926) Vol. I, 107. 


\section{C - In the Euchologion}

We read in the Euchologion, ${ }^{46}$ in the Litany of peace which is a distinctively Egyptian feature ${ }^{47}$

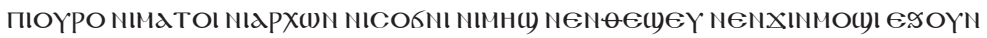

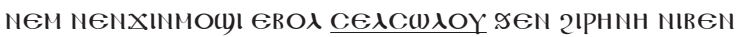

The king, the soldiers, the notables, the councillors, the peoples, our neighbours, our inside ways and our outside ways (adorned / comfort) them with whole peace ${ }^{48}$

The meaning here is not clear whether the verb cexcoloy is for the king, the soldiers or for the ways.

The Arabic version of the Greek version ${ }^{49}$

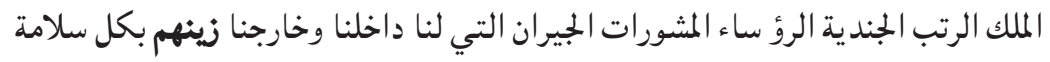

The Litany for the place from the Anaphora of Saint Gregory, we $\operatorname{read}^{50}$

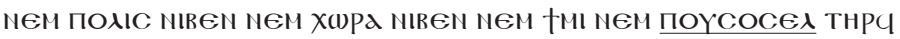

and all the cities and countries and towns and their whole adornment (consolation- universe) ${ }^{51}$

This part is not attested in the edition of Tukhi. ${ }^{52}$

(46) We will refer to the best edition of this book prepared by Abd al-Masih Salib and printed by Claudius Labib which is considered as nearly critical edition cf. U. Zanetti, Esquisse d'une typologie des Euchologes Coptes Bohaïriques, Le Muséon 100 (1987) 407-418.

(47) Cf. G. J. Cuming, The liturgy of St Mark (Roma, 1990) (Orientalia Christiana Analecta, 234) 100.

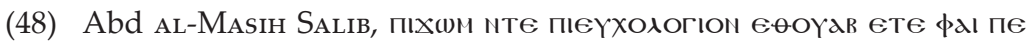

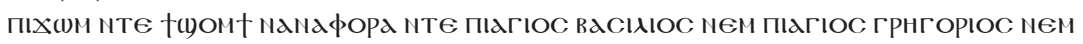
піагіос күрілАос пем ганкеєүхн еүоүав. [The book of the Holy Euchologion which is the book of the three anaphorae of St. Basil, St. Gregory and St. Cyril and other holy prayers] (Cairo, 1902) 278, (liturgy of St Cyril) 581.

(49) Samir KHALIL, La version arabe du Basile alexandrin (codex Kacmarcik), OCP 44 (1978) 342-390 especially p. 364-365.

(50) E. Hammerschmid, Die Koptische Gregoriosanaphora. Syrische und Griechische Einflusse auf Eine Ägyptische Liturgie (Berlin, 1957); IDEM, Some remarks on the History of, and Present State of Investigation into, the Coptic Liturgy, BSAC 19 (1968) 89-113.

(51) Abd al-Masin Salib, піхшм nте пıєүхологіon..., 517.

(52) R. TuкнI, The book of the three anaphoras which are those of Saint Basil, Saint Gregory the Theologian and Saint Cyril with other holy prayers (Roma, 1736). 


\section{D - In the Literature}

This word occurs only once in the Apophthegmata Patrum in Coptic

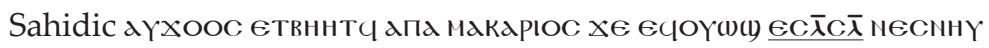
пехас.

It was said about Abba Macarius that he wished to comfort the brethren, he said:.. ${ }^{53}$

This text is translated from the Greek:

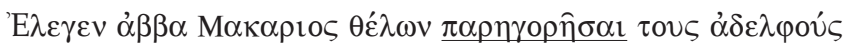
Abba Macarius, wishing to comfort the brethren, said: ... ${ }^{54}$

This word occurs also in a letter addressed from Theophilus the Patriarch to the monks in Coptic

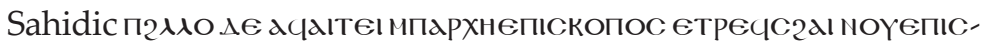

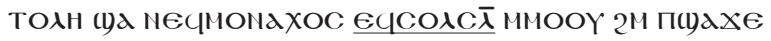

The elder asked the archbishop to write a letter to his monks comforting them with a word....55

\section{Conclusion}

This note shows once more the importance of the study of the Coptic liturgical texts. It highlights the Egyptian way of using pun to express a deep meaning.

It demonstrates also the Coptic origin of the Theotokia.

Sometimes it is difficult to choose which meaning of this word is meant. This is apparent from the above examples.

In our study, we did not take in consideration the meaning of codces as world (not mentioned by Crum) but attested only once in the Epistle of James 3:6

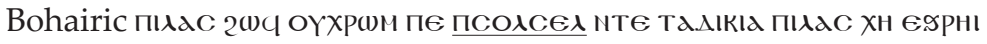

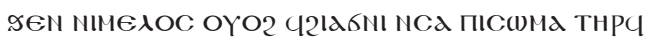

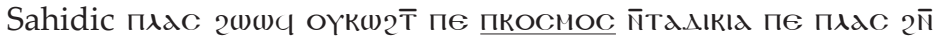

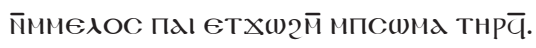

(53) M. Châ̂Ne, Le manuscrit de la version copte en dialecte sahidique des «Apophtehgmata Patrum» BEC 6 (Caire, 1960) 45 N182

(54) J.-C. Guy, Les Apophtegmes des Pères, Collections systématique, Chapitre XVII-XXI (SC, 498) (Paris, 2005) 62-63, N 15

(55) W. E. Crum, Der Papyruscodex saec. VI-VII der Phillippsbibliothek in Cheltenham (Strassburg, 1915) (Schriften der Wissenschaftlichen Gesellschaft in Strassburg, 18) 16: 14-15. 
And the tongue [is] a fire, a world of iniquity: so is the tongue among our members, that it defiles the whole body.

It is important to mention the Greek verb коб $\mu \varepsilon \omega$ has the following

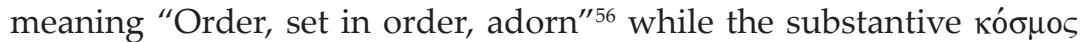
has three meaning of ornament or world $\underline{57}$ or order, or ornament deco-

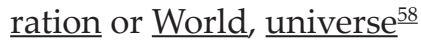

\section{Note ON The Bohairic TheOtokia and the Sahidic Antiphonarion}

The Antiphonarion is an important liturgical book. The Sahidic version dated in 893AD ${ }^{59}$ has been edited by Marie Cramer and Martin Krause, ${ }^{60}$ the Bohairic version dated 1385 is not published yet. ${ }^{61}$

In a previous article, Yassa Abd al-Masih demonstrated that many parts of the actual doxologies have similarities with the Antiphonarion of Hamouli. ${ }^{62}$

Dr Gawdat followed this study with two articles about the compostion and the origin of this book. ${ }^{63}$

In his book of the Lamp of Darkness, Ibn Kabar indicates that the use of the Theotokias is not observed in the Upper Egypt ${ }^{64}$

(56) G. W. H. Lampe, A Patristic Greek Lexicon (Oxford, 1961) 769a

(57) Liddell-Scott, 985.

(58) Lampe, A Patristic Greek Lexicon..., 771ab.

(59) L. Depuyd, Catalogue of Coptic Manuscripts in the Pierpont Morgan Library (Leuven: Peeter, 1993) (Corpus of Illuminated Manuscrispts) Vol. 1, 107-112.

(60) M. Cramer, M. Krause, Das koptische Antiphonar (Jerusalemer Theologisches Forum, 12) (Münster: Aschendorff, 2008).

(61) Nashaat Mekhaiel, Shenoute as reflected in the Vita and the Difnar, in: Gawdat Gabra, Hany N. TAKLA (eds.), Christianity and Monasticism in Upper Egypt - Akhmim and Sohag, vol. I (Cairo-New York: The American University in Cairo Press, 2008) 99-106.

(62) Yassa 'Abd AL-Masin, Doxologies of the Coptic Church, BSAC 5 (1939) 175-191.

(63) For a study of this book cf. Gawdat GABRA, Untersuchungen zum Difnar der koptischen Kirche. I Quellenlage, Forschungsgeschichichte und künftige Aufgaben, BSAC 35 (1996) 37-52; IDEM, Untersuchungen zum Difnar der koptischen Kirche. II zur Kompilation, BSAC 37 (1998) 49-68.

(64) L. Villecourt, Les observances Liturgiques et la discipline du jeûne dans l'Église Copte, Le Muséon 37 (1924) 201-280 especially p. 229. 
In previous studies, I discussed the origin and the evolution of the theotokias and I compared with the patristic texts. ${ }^{65}$ I concluded that some parts of the Theotokias are present in the Sahidic Antiphonarion. ${ }^{66}$

Muyser compared the Bohairic theotokia and the Antiphonary, ${ }^{67}$ I will reproduce the list and I will compare the two texts to comment on the linguistic evolution of the texts. We choose to compare in details the theotokia of Tuesday and Wednesday as representing to the tune Adam and Batos. We added also the unique stanza from the theotokia for Sundays and the table showing the correspondence between the theotokias of Thursday and Friday.

\section{Theotokia of Sunday}

Only one stanza was found in the Antiphonarion that resembles to the stanza of Sunday Theotokia.

\begin{tabular}{|c|c|c|}
\hline Antiphonarion ${ }^{69}$ & $\begin{array}{l}\text { Theotokia of Sunday } \\
\text { (part 1) }\end{array}$ & Translation \\
\hline 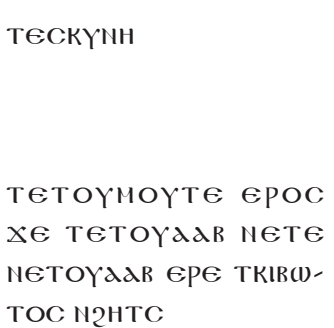 & 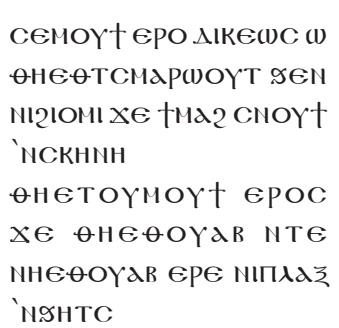 & $\begin{array}{l}\text { You are justly called, } \\
\text { o blessed one, among } \\
\text { women, the Second } \\
\text { Tabernacle } \\
\text { Which is called, the } \\
\text { holy of the Holies, } \\
\text { wherein are the } \\
\text { tablets }\end{array}$ \\
\hline
\end{tabular}

\section{Commentary}

The Sahidic version of the Antiphonarion is slightly different from the Bohairic

"The Tabernacle which is called the holy of Holies wherein the Ark"

(65) Youssef, Severus of Antioch..., 93-108 ; IDEM, The Coptic Marian..., 127-140; IDEM, Note sur La Vierge Marie Entre la tradition Copte et Syriaque (Maronite), Parole de l'Orient 31 (2006) 185-190.

(66) Youssef, Une relecture des Théotokies..., 153-170 especially p. 170.

(67) J. Muyser, Maria's Heerlikleid in Egypten Ein Studie der Koptische Maria Literature, vol. I (Louvain, 1935) 60-74 and especially p. 72-74.

(68) Cramer, Krause, Das koptische Antiphonar..., 106. 
It resembles to the first two stanzas of the Theotokia of Sunday, however the Bohairic text talk about the "Tablets" while the Sahidic version mentions the "Ark"

\section{Theotokia of Monday}

I was unable to find any text in both books resembles to each other.

\section{Theotokia of Tuesday}

There are two parts from the Theotokia of Tuesday which have their counterpart in the Sahidic book of the Antiphonarion.

\begin{tabular}{|c|c|c|}
\hline Antiphonarion $^{70}$ & $\begin{array}{l}\text { Theotokia of Tuesday } \\
\text { (part 2) }\end{array}$ & Translation \\
\hline 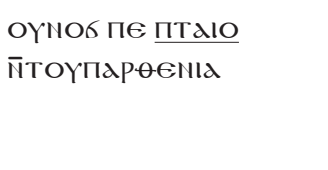 & 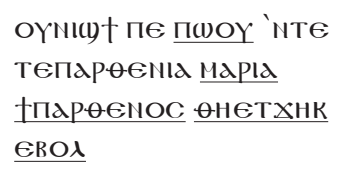 & $\begin{array}{l}\text { Great is the glory } \\
\text { of your virginity, } \\
\text { O Virgin Mary, the } \\
\text { perfect one }\end{array}$ \\
\hline 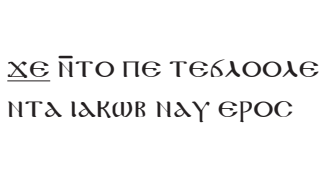 & 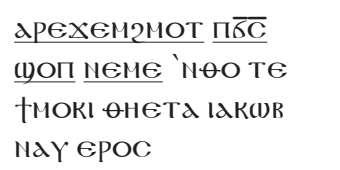 & $\begin{array}{l}\text { You have found grace, } \\
\text { and the Lord is with } \\
\text { you, you are the lad- } \\
\text { der, which Jacob saw }\end{array}$ \\
\hline 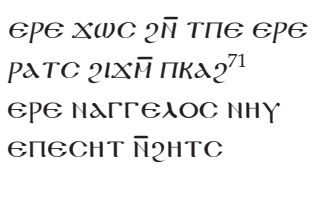 & 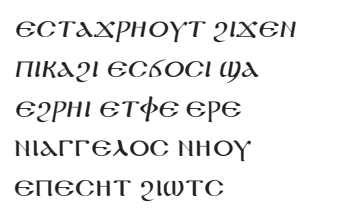 & $\begin{array}{l}\text { Set firmly on the earth, } \\
\text { reaching to heaven, } \\
\text { where the angels come } \\
\text { down upon it }\end{array}$ \\
\hline 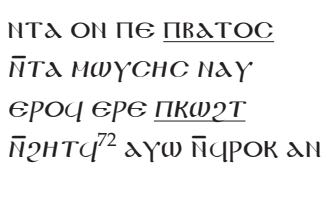 & 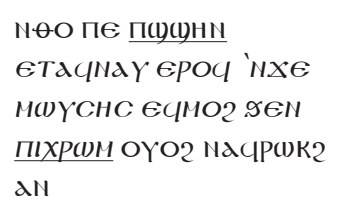 & $\begin{array}{l}\text { You are the bush, } \\
\text { which Moses has seen } \\
\text { flaming with fire and } \\
\text { was not consumed }\end{array}$ \\
\hline
\end{tabular}

(69) Cramer, Krause, Das koptische Antiphonar..., 182 N 164.

(70) Which its head is in heaven and its feet on the earth.

(71) When Moses saw it while the fire in it. 


\begin{tabular}{|c|c|c|}
\hline ונוזונותו & 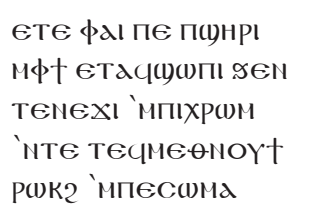 & $\begin{array}{l}\text { Who is the Son of } \\
\text { God, who dwelt in } \\
\text { your womb, the fire } \\
\text { of His Divinity did not } \\
\text { consume your body }\end{array}$ \\
\hline 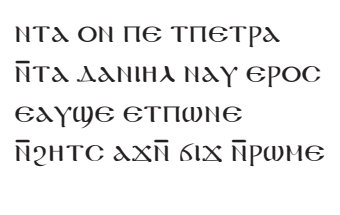 & //////////////I & $\begin{array}{l}\text { You are also the stone } \\
\text { which Daniel saw it } \\
\text { in a wood separated } \\
\text { from it without hum- } \\
\text { an hand }\end{array}$ \\
\hline 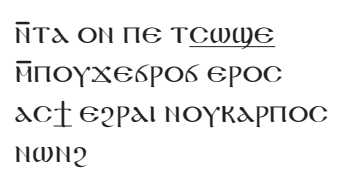 & 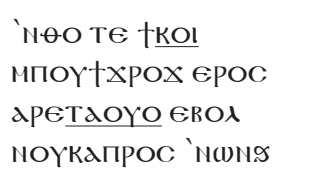 & $\begin{array}{l}\text { You are also the field } \\
\text { which was not seeded } \\
\text { and gave a fruit of } \\
\text { life }\end{array}$ \\
\hline 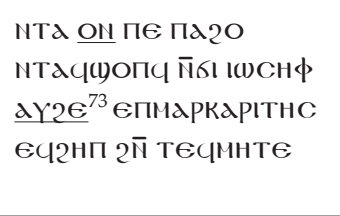 & 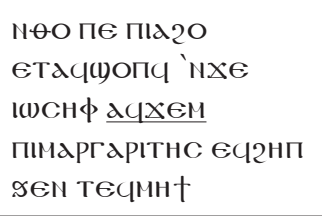 & $\begin{array}{l}\text { You are the treasure } \\
\text { that Joseph bought } \\
\text { and he found the } \\
\text { pearl, hidden in its } \\
\text { midst }\end{array}$ \\
\hline 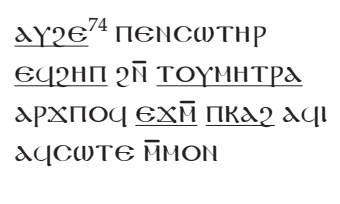 & 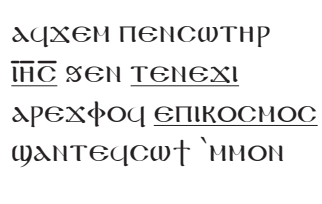 & $\begin{array}{l}\text { He found our Saviour } \\
\text { Jesus in your womb, } \\
\text { you gave birth to Him } \\
\text { for the world so He } \\
\text { might save us }\end{array}$ \\
\hline
\end{tabular}

\section{Commentary}

- The translation provided here is based mainly on the Bohairic text.

- We find some minor changes such as in stanza 1 Tdı "honour" Sahidic and "woY" "glory" Bohairic. Stanza 5 "Tcweye Sahidic and "†коІ" Bohairic. Stanza 6 "дү2є" in Sanidic, "дчхем" in Boahric.

- Addition of a sentence in one stanza, as in stanza 1 Bohairic "Mapld

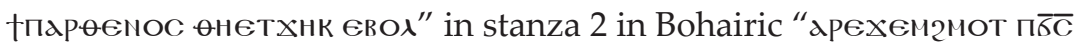
(1)оп неме

- Addition of a complete stanza as in stanza 5 in both Sahidic and Bohairic

(72) Lit "a pearl was found.

(73) Lit. "our Saviour was found." 
- Change in the formulation however the meaning is the same as

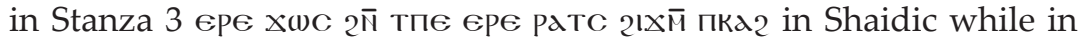
Bohairic єстахрноүт 2ıхен пाкд2ı єебосı Stanza 4.

- Change Coptic word into Greek as Stanza 4 ватос Sahidic пюумнн Bohairic, Stanza 7 "тоүмнтрд" Sahidic, "темехı" Bohairic, "пкд2" Sahidic, "пикосмос" Bohairic.

- Addition of words such as xe in stanza 2, Sahidic, Stanza 6 or Sahidic, Stanza 7 " $\overline{\mathrm{i}} \overline{\mathrm{C}}$ " Bohairic.

- Change of the person such as in stanza 5 " $\mathrm{dct}$ " she gave" Sahidic "apetdoro" You gave. It is important to mention that the beginning of the stanza is addressed to the Virgin using the $2^{\text {nd }}$ person.

\begin{tabular}{|c|c|c|}
\hline Antiphonarion ${ }^{75}$ & $\begin{array}{l}\text { Theotokia of Tuesday } \\
\text { (part 5) }\end{array}$ & Translation \\
\hline 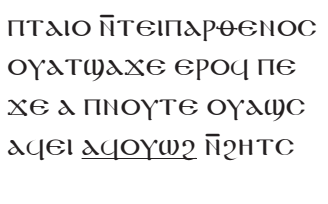 & 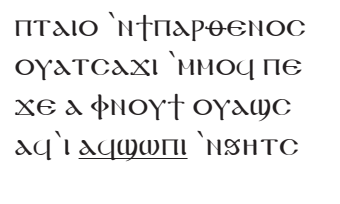 & $\begin{array}{l}\text { The honour of the } \\
\text { Virgin is unutterable, } \\
\text { for God desired her } \\
\text { and came and dwelt } \\
\text { in her }\end{array}$ \\
\hline 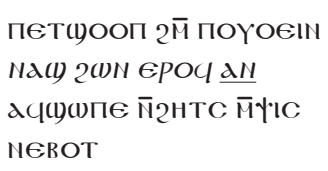 & 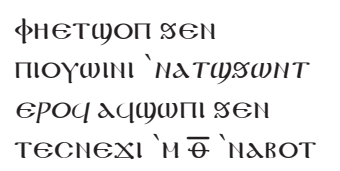 & $\begin{array}{l}\text { He who abides in light } \\
\text { that is unapproachable, } \\
\text { dwelt in her womb, for } \\
\text { nine months }\end{array}$ \\
\hline 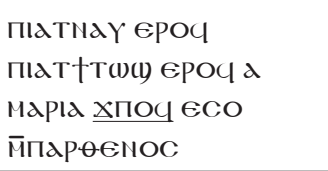 & 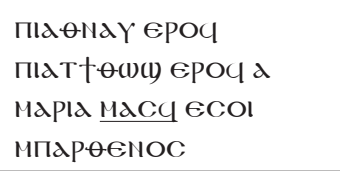 & $\begin{array}{l}\text { Mary gave birth to } \\
\text { the Invisible and the } \\
\text { Infinite, One and } \\
\text { remained Virgin }\end{array}$ \\
\hline 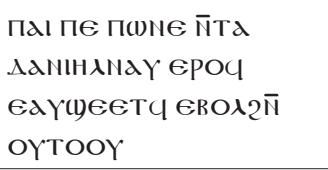 & 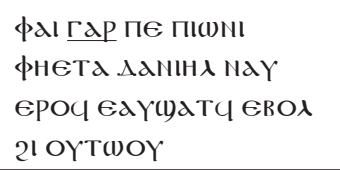 & $\begin{array}{l}\text { This is the rock which } \\
\text { Dasniel saw which was } \\
\text { cut from a mountain }\end{array}$ \\
\hline 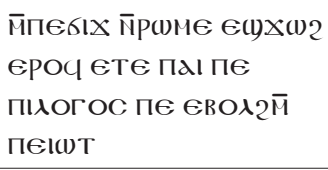 & 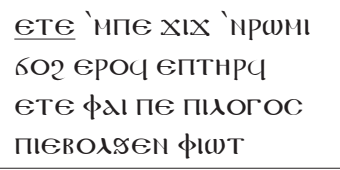 & $\begin{array}{l}\text { The hands of men, } \\
\text { never touched Him, } \\
\text { for He is the Word of } \\
\text { the Father }\end{array}$ \\
\hline 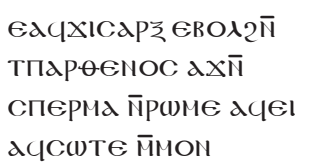 & 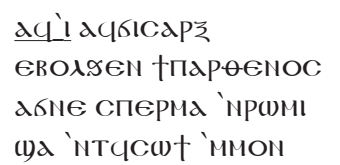 & $\begin{array}{l}\text { He came and took } \\
\text { flesh, from the Virgin, } \\
\text { without the seed of } \\
\text { manin order to save us }\end{array}$ \\
\hline
\end{tabular}

(74) Cramer, Krause, Das koptische Antiphonar..., 184, N 167. 


\section{Commentary}

- The translation provided here is based mainly on the Bohairic text.

- We find some minor changes such as in stanza 1 dy yorw2 Sahidic

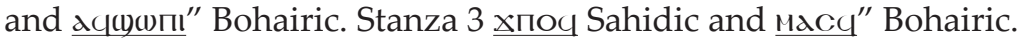

- Addition of a complete stanza as in stanza 5 in both Sahidic and Bohairic

- Change in the formulation however the meaning is the same as in Stanza 3 Na $2 \omega N$ ePOC a $N$ in Shaidic while Natyswnt in Bohairic.

- Addition of words such as rap in stanza 4, Bohairic, Stanza 5 eте Bohairic. stanza 6 " $\mathrm{d} 4 \iota_{1}$ " Bohairic.

\section{Theotokia of Wednesday}

The entire Theotokia of Wednesday occurs in the book of the Antiphonarion

\begin{tabular}{|c|c|c|}
\hline Antiphonarion ${ }^{76}$ & $\begin{array}{c}\text { Theotokia of } \\
\text { Wednesday (part 1) }\end{array}$ & Translation \\
\hline 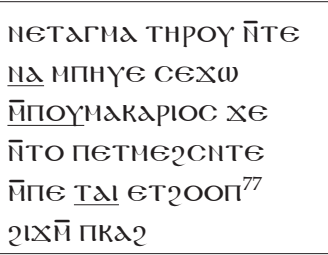 & 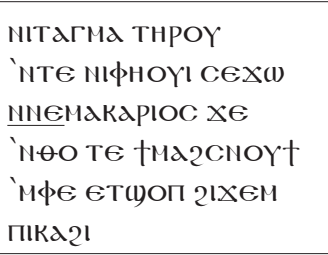 & $\begin{array}{l}\text { All the heavenly } \\
\text { ranks declare your } \\
\text { blessedness, for you } \\
\text { are the Second Heaven } \\
\text { upon earth }\end{array}$ \\
\hline 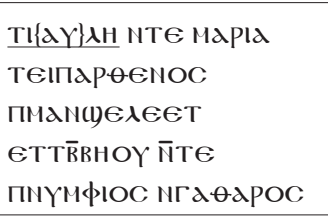 & 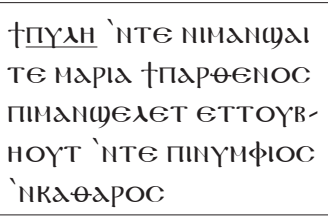 & $\begin{array}{l}\text { The gate of the East } \\
\text { is the Virgin Mary, } \\
\text { the pure bridal cham- } \\
\text { ber for the pure Bride- } \\
\text { groom }\end{array}$ \\
\hline 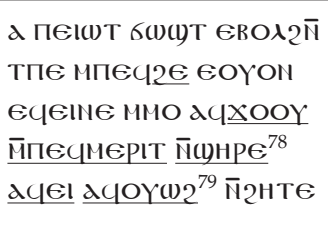 & 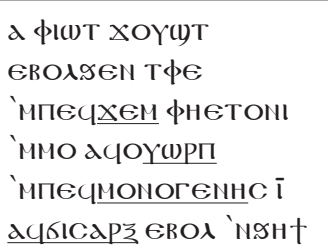 & $\begin{array}{l}\text { TheFatherlooked from } \\
\text { heaven and found no } \\
\text { one that resembles } \\
\text { you. He sent His Only } \\
\text { Begotten who came } \\
\text { and tookflesh from you }\end{array}$ \\
\hline
\end{tabular}

(75) Cramer, Krause, Das koptische Antiphonar..., 212, N 207.

(76) Read "Етуооп" I am not sure whether it is a misprint or mistake from the scribe of the manuscript.

(77) "His Beloved Son."

(78) "and abode in you." 


\section{Commentary}

- The translation provided here is based mainly on the Bohairic text.

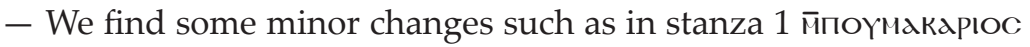
Sahidic and "мпемдкаріос" Bohairic. Stanza 3 xоo Sahidic and оүшрп Bohairic

- The reconstruction of the editor for the first word of stanza 2 in Sahidic is probable however Bohairic is more probable. It seems that the scribe did not copy the word Mmman(y).

- Addition of words such as Tal in stanza 1, Sahidic,.

- Change in the formulation however the meaning is the same as in Stanza 3 дахооү м̄песмеріт їсунре "He sent his Beloved Son" in Shaidic while in Bohairic асоүшрп 'мпесмоногеннс. "He sent His Only Begotten. The same could be said acyorw2 "dwelt" in Sahidic while in Bohairic aç6ıсар乏 "took flesh

\begin{tabular}{|c|c|c|}
\hline Antiphonarion $^{80}$ & $\begin{array}{c}\text { Theotokia } \\
\text { of Wednesday } \\
\text { (part 2) }\end{array}$ & Translation \\
\hline 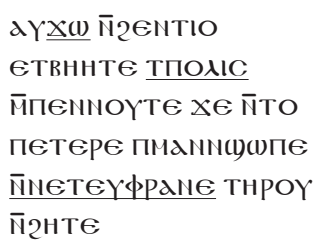 & 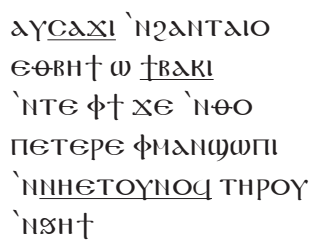 & $\begin{array}{l}\text { They spoke of you } \\
\text { with honour, O city of } \\
\text { God, for you are the } \\
\text { dwelling place of all } \\
\text { the joyful }\end{array}$ \\
\hline 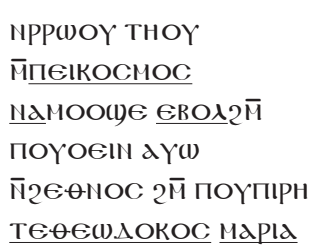 & 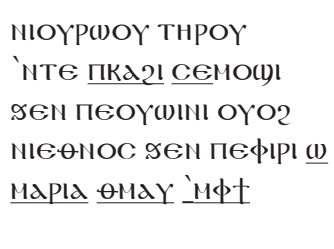 & $\begin{array}{l}\text { All the kings of the } \\
\text { earth walk in your } \\
\text { light and the nations } \\
\text { in your brightness, } \\
\text { O Mary the Mother } \\
\text { of God }\end{array}$ \\
\hline 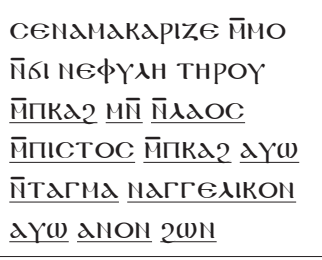 & $\begin{array}{l}\text { сеєрмдкаріzім 'ммо } \\
\text { нхє мігенєа тнроү }\end{array}$ & $\begin{array}{l}\text { Every generation bles- } \\
\text { ses you and }\end{array}$ \\
\hline
\end{tabular}

(79) Cramer, Krause, Das koptische Antiphonar..., 208, N 198. 


\begin{tabular}{|c|c|c|}
\hline 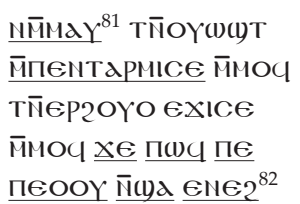 & 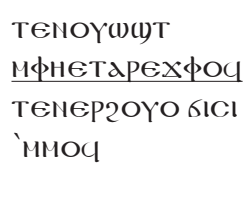 & $\begin{array}{l}\text { we worship Him to } \\
\text { whom you gave birth } \\
\text { and we exalt you }\end{array}$ \\
\hline
\end{tabular}

\section{Commentary}

- The translation provided here is based mainly on the Bohairic text.

- We find some minor changes such as in stanza 1 xw "say" Sa-

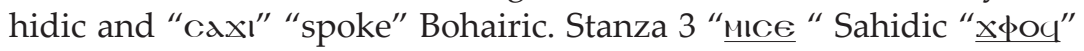
Bohairic

- Addition of a sentence in one stanza, as in stanza 3 Sahidic

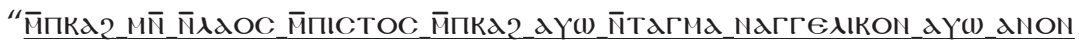

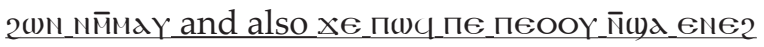

- Change Coptic word into Greek as Stanza 1 полıс Sahidic †вдкı Bohairic, Stanza 1 "Eүфpane" Sahidic, "oүnoy" Bohairic, Stanza 2 "пикосмос" Sahidic, "пкд2" Bohairic. Stanza 3 тєөєш.докос Sahidic өmaY mф† Bohairic

\begin{tabular}{|c|c|c|}
\hline Antiphonarion $^{83}$ & $\begin{array}{c}\text { Theotokia of } \\
\text { Wednesday (part 3) }\end{array}$ & Translation \\
\hline 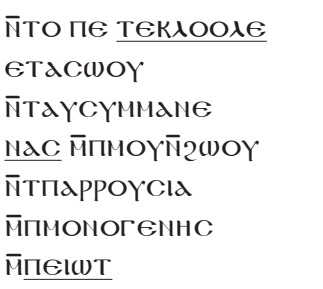 & 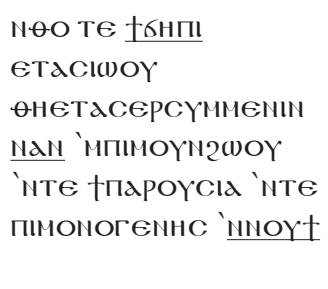 & $\begin{array}{l}\text { You are the light cloud } \\
\text { that has lead us to the } \\
\text { rain of the advent of } \\
\text { the Only Begotten of } \\
\text { God }\end{array}$ \\
\hline 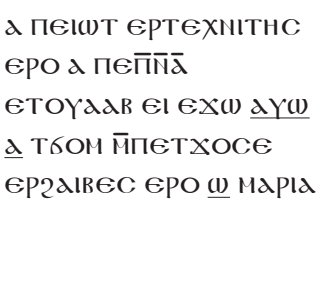 & 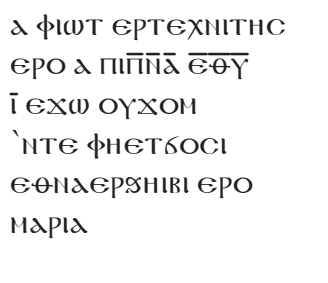 & $\begin{array}{l}\text { The Father created } \\
\text { you skilfully the } \\
\text { Holy Spirit came } \\
\text { upon you and the } \\
\text { Power of the Highest } \\
\text { overshadowed you, } \\
\text { Mary }\end{array}$ \\
\hline
\end{tabular}

(80) "Of the earth and the faithful peoples and the angelic ranks and we also with them."

(81) For Glory be to Him forever.

(82) Cramer, Krause, Das koptische Antiphonar..., 208, N 197. 


\begin{tabular}{|c|c|c|}
\hline 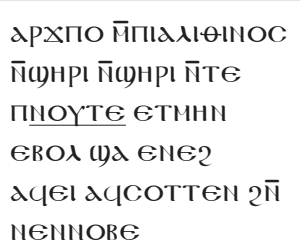 & 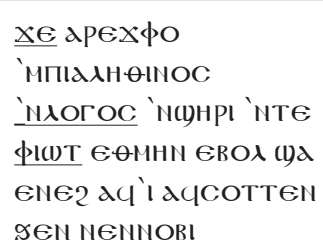 & $\begin{array}{l}\text { For you have given } \\
\text { birth to the True Word, } \\
\text { the Son of the Ever } \\
\text { existing Father, whom } \\
\text { came and save us from } \\
\text { our sins }\end{array}$ \\
\hline
\end{tabular}

\section{Commentary}

- The translation provided here is based mainly on the Bohairic text.

- We find some minor changes such as in stanza 1 текıоoлe Sahidic and "†бнпı" Bohairic.

- Addition of words such as xe in stanza 3, Bohairic, Stanza 2 a $ү(1$ a Sahidic, Stanza 7 "ī $\overline{\mathrm{C}}$ ".

- Change of the person such as in stanza 1 " $\mathrm{NdC}$ " to her" Sahidic "Nav" to us". It is important to mention that the beginning of the stanza is addressed to the Virgin using the $2^{\text {nd }}$ person hence the Bohairic is more logic.

- In stanza 1, 3 there is an interchange between the Father and God in both ways

\begin{tabular}{|c|c|c|}
\hline Antiphonarion $^{84}$ & $\begin{array}{c}\text { Theotokia } \\
\text { of Wednesday } \\
\text { (part } 4)\end{array}$ & Translation \\
\hline 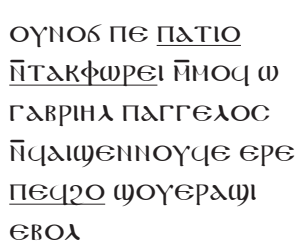 & 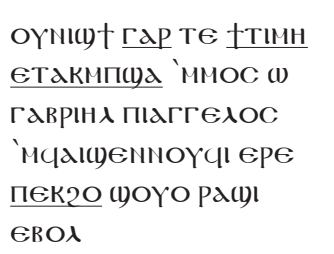 & $\begin{array}{l}\text { For great s the hon- } \\
\text { our which you are } \\
\text { worthy of O Gabriel, } \\
\text { the messenger Angel, } \\
\text { your face beams with } \\
\text { joy }\end{array}$ \\
\hline 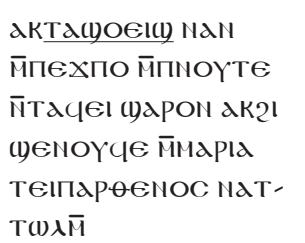 & 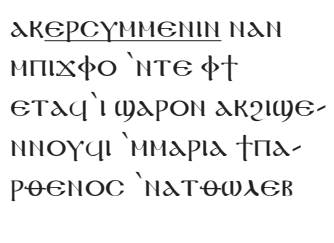 & $\begin{array}{l}\text { You announced to us } \\
\text { the birth of God who } \\
\text { came to us and you } \\
\text { declared to Mary the } \\
\text { undefiled Virgin }\end{array}$ \\
\hline
\end{tabular}

(83) Cramer, Krause, Das koptische Antiphonar..., 198, N 184. 


\begin{tabular}{|c|c|c|}
\hline 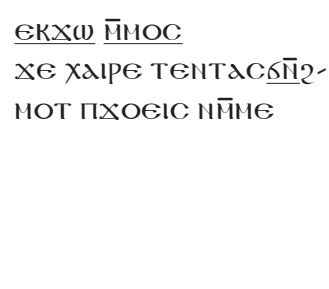 & 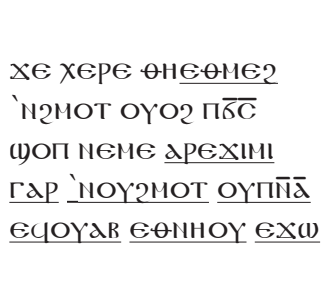 & $\begin{array}{l}\text { Saying: } \\
\text { "Hail to you O full } \\
\text { of grace, the Lord is } \\
\text { with you, you have } \\
\text { found favour, the } \\
\text { Holy Spirit shall } \\
\text { come upon you." }\end{array}$ \\
\hline 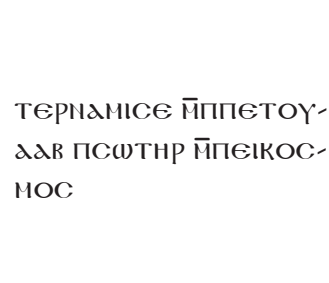 & 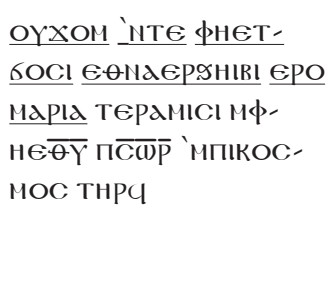 & $\begin{array}{l}\text { The power of the } \\
\text { Highest will over- } \\
\text { shadow you Mary, } \\
\text { you shall give birth } \\
\text { of to the Holy, the } \\
\text { Saviour of the whole } \\
\text { world }\end{array}$ \\
\hline
\end{tabular}

\section{Commentary}

- The translation provided here is based mainly on the Bohairic text.

- We find some minor changes such as in stanza 3 сбйгмот "find grace" Sahidic and "өнеөме2 'нгмот" "full of grace" Bohairic.

- Addition of a sentence, as in stanza 3 Sahidic "ЕкXw Mмос" in

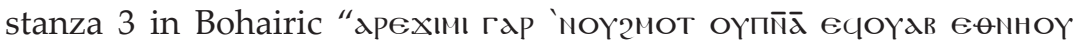
exw and in stanza 4 Bohairic оүхом 'нте фнетбос єөндерянıвı еро Mapla

- Change Coptic word into Greek as Stanza 1 таı Sahidic тимн

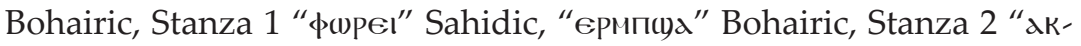
та(yoeıc)" Sahidic, "дкерсүмнемим" Bohairic.

- Change of the person such as in stanza 1 "печ20" his face" Sahidic "пекго" Your face. It is important to mention that the beginning of the stanza is addressed to the Virgin using the $2^{\text {nd }}$ person.

\begin{tabular}{|c|c|c|}
\hline Antiphonarion ${ }^{85}$ & $\begin{array}{c}\text { Theotokia } \\
\text { of Wednesday } \\
\text { (part 5) }\end{array}$ & Translation \\
\hline 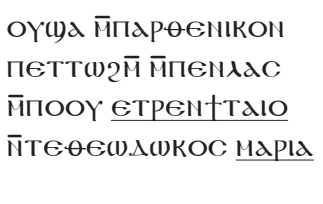 & 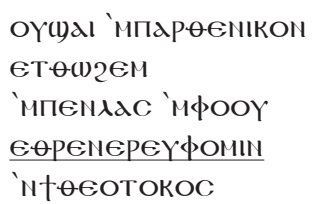 & $\begin{array}{l}\text { A virginal feast, today, } \\
\text { called our tongues to } \\
\text { give praise to Mary, } \\
\text { the Mother of God }\end{array}$ \\
\hline
\end{tabular}

(84) Cramer, Krause, Das koptische Antiphonar..., 164, N 143. 


\begin{tabular}{|c|c|c|}
\hline Antiphonarion & $\begin{array}{c}\text { Theotokia } \\
\text { of Wednesday } \\
\text { (part 5) }\end{array}$ & Translation \\
\hline 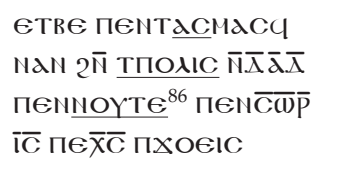 & 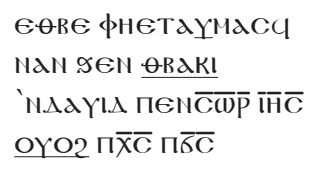 & $\begin{array}{l}\text { Because who was born } \\
\text { for us in the City of } \\
\text { David, our Saviour } \\
\text { Jesus Christ the Lord }\end{array}$ \\
\hline 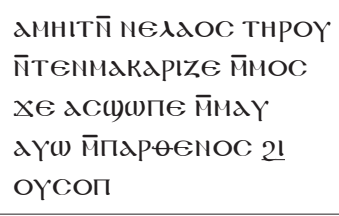 & 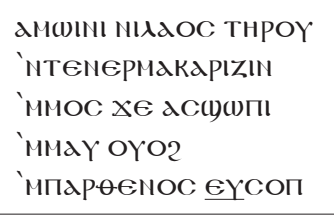 & $\begin{array}{l}\text { Come all you nation. } \\
\text { So we may give bles- } \\
\text { sings to her for she } \\
\text { has become both the } \\
\text { Mother and Virgin }\end{array}$ \\
\hline 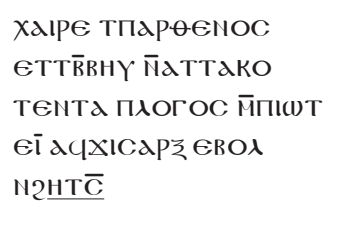 & 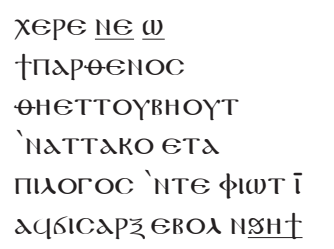 & $\begin{array}{l}\text { Hail to You, O Virgin, } \\
\text { the pure and incorrupt } \\
\text { one, the Word of the } \\
\text { Father, came and took } \\
\text { flesh from you. }\end{array}$ \\
\hline 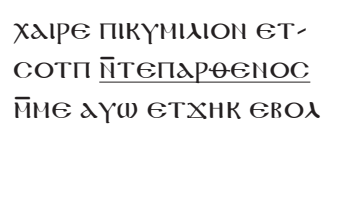 & 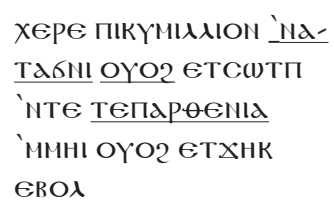 & $\begin{array}{l}\text { Hail to the chosen } \\
\text { vessel which is with- } \\
\text { out blemish that is of } \\
\text { your true and perfect } \\
\text { virginity }\end{array}$ \\
\hline 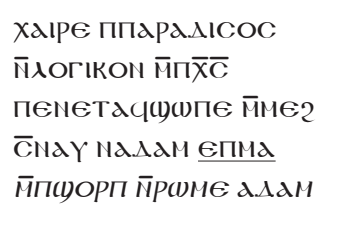 & 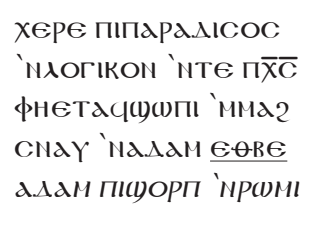 & $\begin{array}{l}\text { Hail to the rational } \\
\text { Paradise of Christ, } \\
\text { who became the } \\
\text { Second Adam for the } \\
\text { sake of Adam the first } \\
\text { man }\end{array}$ \\
\hline 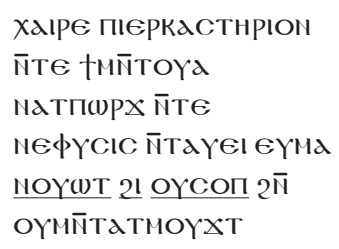 & 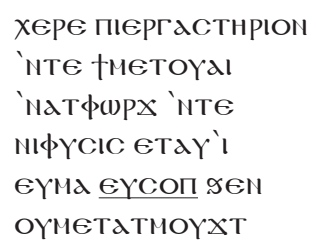 & $\begin{array}{l}\text { Hail to the uniting } \\
\text { place of the unsep- } \\
\text { arated natures, that } \\
\text { came together in one } \\
\text { place without ever } \\
\text { mingling }\end{array}$ \\
\hline
\end{tabular}

(85) Our God. 


\begin{tabular}{|c|c|c|}
\hline 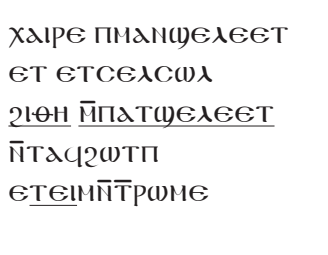 & 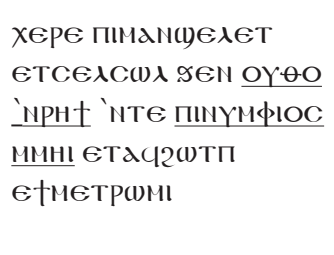 & $\begin{array}{l}\text { Hail to the bridal } \\
\text { chamber adorned in } \\
\text { every way, for the } \\
\text { true Bridegroom, who } \\
\text { united with human- } \\
\text { ity. }\end{array}$ \\
\hline 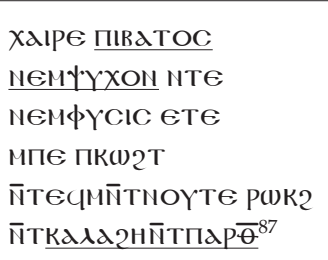 & 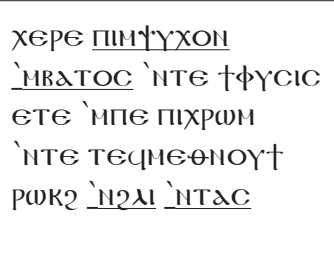 & $\begin{array}{l}\text { Hail to cool bush by } \\
\text { nature, which the fire } \\
\text { of His Divinity did not } \\
\text { consume any of it }\end{array}$ \\
\hline 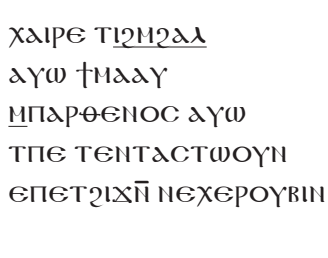 & 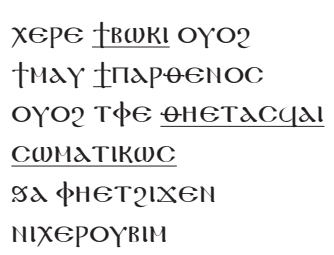 & $\begin{array}{l}\text { Hail to thehandmaiden } \\
\text { and mother, the Virgin } \\
\text { and the heaven, who } \\
\text { carried in the flesh, } \\
\text { He who sits upon the } \\
\text { Cherubim. }\end{array}$ \\
\hline 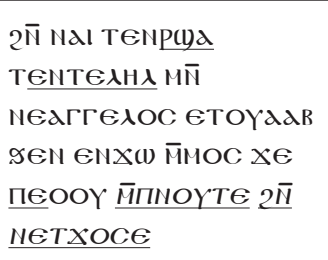 & 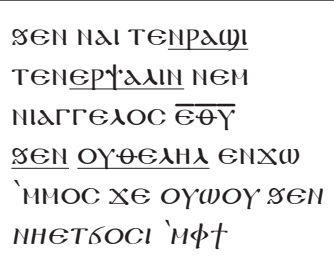 & $\begin{array}{l}\text { Therefore we rejoice } \\
\text { and sing with the holy } \\
\text { Angels and we joyful- } \\
\text { ly proclaim: "Glory } \\
\text { to in the Highest to } \\
\text { God" }\end{array}$ \\
\hline 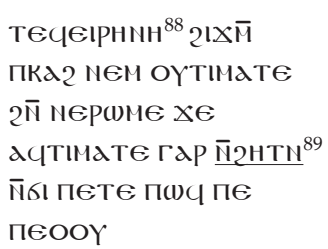 & 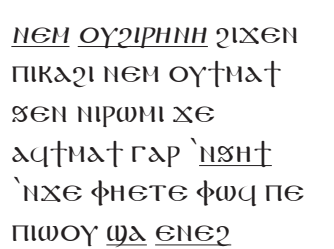 & $\begin{array}{l}\text { "And in Earth peace, } \\
\text { goodwill toward } \\
\text { men." For He was } \\
\text { pleased with you to } \\
\text { whom is the glory } \\
\text { forever, }\end{array}$ \\
\hline
\end{tabular}

\section{Commentary}

- The translation provided here is based mainly on the Bohairic text.

- We find some minor changes such as in stanza $3 \&$ stanza 721 оүсоп Sahidic and "єүсоп" Bohairic, stanza 6 єпмд "in the place

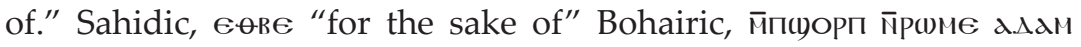

(86) Womb of the Virgin.

(87) His peace.

(88) With us. 
"for the first man Adam" Sahidic, д.лдм пиюорп 'мрюм "Adam the first man, Bohairic. Stanza 9 we find пввдтос немүүхон in Sahidic while пимүүхон 'мвдтос in Boahiric. Stanza 10 The word 2m2dג in Sahidic is replaced by вюкı in Boahiric, and also тентдстшоүн" in Sahidic has ө૯нтдссал in Bohiairic." Or in Stanza 11 we have темр(yd "We make feast" in Sahidic while in Bohairic is Tempa(y) "we rejoice"

- Change Coptic word into Greek as Stanza 1 eтpen†таı Sahidіс еөренереүфомим Bohairic, Stanza 2 тпольс Sahidic өвдк Bohairic, Stanza 8 мппдтуелеет Sahidic "пичүмфюос Bohairic, in stanza 11 тентелнд in Sahidic became "темерүали" in Boiahiric

- Addition of words such as пенноүте in stanza 2, Sahidic, Stanza 4 "Ne w" Stanza 5 " "нatám oyo2" Bohairic

- Change of the person such as in stanza 4 "н2нт $\overline{\mathrm{C}}$ " from her" Sahidic "NaHt" from you" Bohairic. It is important to mention that the beginning of the stanza is addressed to the Virgin using the $2^{\text {nd }}$ person. And also in Stanza 12 in Sahidic 푸TN "with us' while in Bohairic nянt "with You" also in Stanza 12 we find тесеірнин "His peace" while in Boahiric "peace".

- Change the substantive into adjective such in stanza 5 тепдpөenoc "The Virgin" Sahidic, тепарөенাа "Vriginity" Bohairic.

- Change in the formulation however Stanza 8 210H "in front of" Shaidic while in Bohairic gen orøo 'upHt in every way. In Stanza 9 we

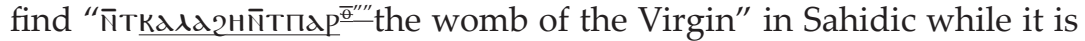
iN2גi 'iTAC "any of it" in Bohairic.

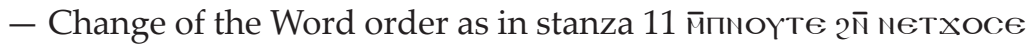
in Sahidic and oywoy gen nнeт бос ' $\mathrm{M \phi}+$ in Bohairic.

\begin{tabular}{|c|c|c|}
\hline Antiphonarion ${ }^{90}$ & $\begin{array}{c}\text { Theotokia of } \\
\text { Wednesday (part 6) }\end{array}$ & Translation \\
\hline 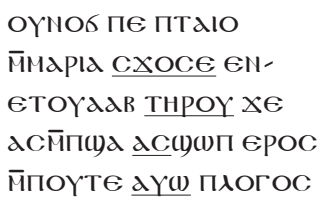 & 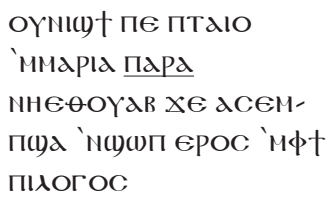 & $\begin{array}{l}\text { Great is the honour } \\
\text { of Mary above all the } \\
\text { saints, for she became } \\
\text { worthy to receive God } \\
\text { the Word }\end{array}$ \\
\hline 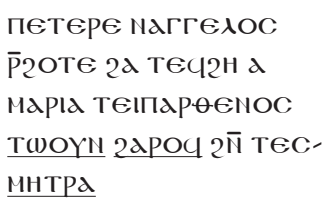 & 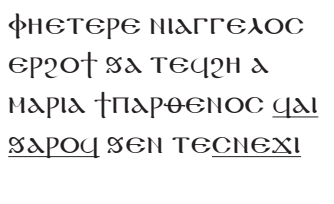 & $\begin{array}{l}\text { The one feared by the } \\
\text { angels, Mary the Vir- } \\
\text { gin, has carried in her } \\
\text { womb }\end{array}$ \\
\hline
\end{tabular}

(89) Cramer, Krause, Das koptische Antiphonar..., 202, N 189. 


\begin{tabular}{|c|c|c|}
\hline 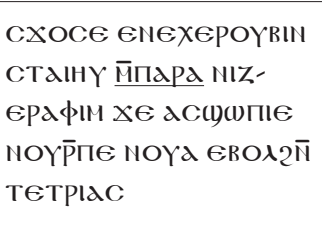 & 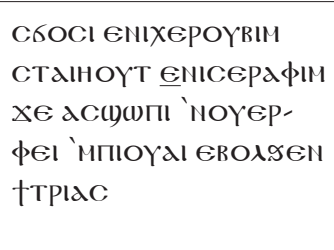 & $\begin{array}{l}\text { She is exalted above } \\
\text { the Cherubim, more } \\
\text { honored than the Sera- } \\
\text { phim, she became a } \\
\text { temple for the One } \\
\text { from the Trinity }\end{array}$ \\
\hline 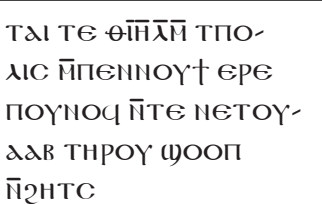 & 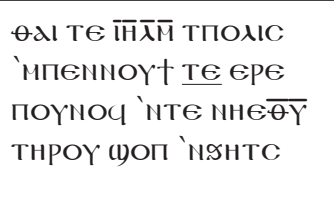 & $\begin{array}{l}\text { This is Jerusalem, the } \\
\text { city of our God, the } \\
\text { joy of all saint abides } \\
\text { in her. }\end{array}$ \\
\hline
\end{tabular}

\section{Commentary} text.

- The translation provided here is based mainly on the Bohairic

- We find some minor changes such as in stanza 1 дсйп(у) дссуюп "She was, she receive" Sahidic and "дсемпюуд 'мююп" "she was worthy in receiving" Bohairic. and also in stanza 2 тшоү" in Sahidic has cal in Bohiairic."

- Change Coptic word into Greek as Stanza 1 "cxoce" "elevetad" Sahidic парג above in Bohairic,. and in Stanza 3 we find the opposite in Sahidic "пара" while in Bohairic $\mathrm{e}$

- Addition of words such as тнро "all" in stanza 1, Sahidic, Stanza 6 or Sahidic, Stanza 7 “ī $\overline{\mathrm{C}}$ ” Bohairic.

\begin{tabular}{|c|c|c|}
\hline Antiphonarion ${ }^{91}$ & $\begin{array}{c}\text { Theotokia } \\
\text { of Wednesday } \\
\text { (part 7) }\end{array}$ & Translation \\
\hline 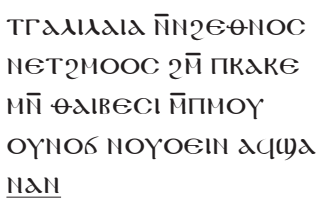 & 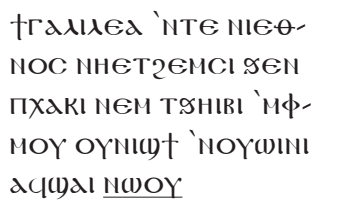 & $\begin{array}{l}\text { Galilee of the nations } \\
\text { who sit in darkness } \\
\text { and in the shadow of } \\
\text { death, had great light } \\
\text { shine to them }\end{array}$ \\
\hline 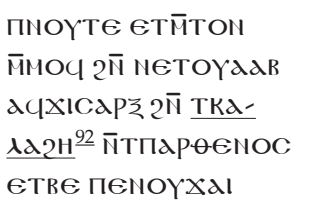 & 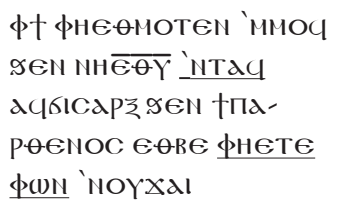 & $\begin{array}{l}\text { God who rests, with } \\
\text { His saints became in- } \\
\text { carnate of the Virgin, } \\
\text { for our salvation }\end{array}$ \\
\hline
\end{tabular}

(90) Cramer, Krause, Das koptische Antiphonar..., 194, N 180.

(91) In the womb. 


\begin{tabular}{|c|c|c|}
\hline Antiphonarion & $\begin{array}{c}\text { Theotokia } \\
\text { of Wednesday } \\
\text { (part 7) }\end{array}$ & Translation \\
\hline 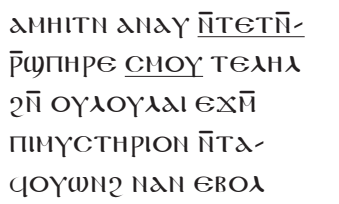 & 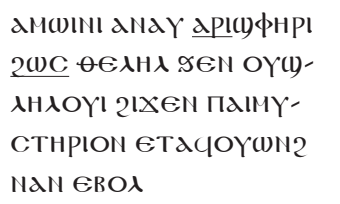 & $\begin{array}{l}\text { Come behold and be } \\
\text { amazed joyfully sing } \\
\text { on account of this } \\
\text { mystery, which was } \\
\text { revealed unto us }\end{array}$ \\
\hline 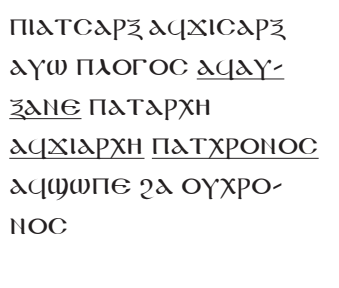 & 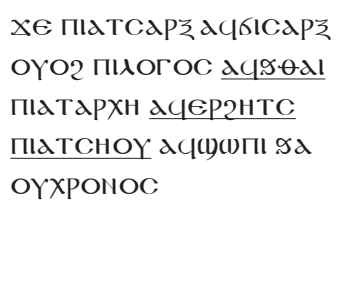 & $\begin{array}{l}\text { For the One without } \\
\text { flesh was incarnated, } \\
\text { and the Word became } \\
\text { thick, the one without } \\
\text { beginning began and } \\
\text { the Eternal one be- } \\
\text { came temporal }\end{array}$ \\
\hline 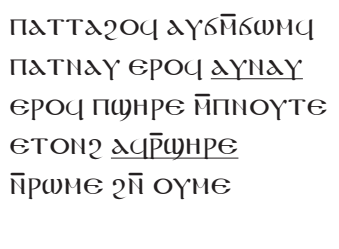 & 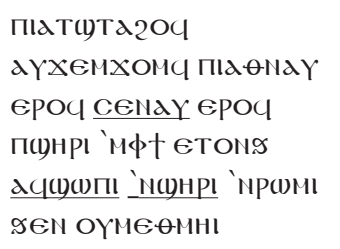 & $\begin{array}{l}\text { The Unlimited has } \\
\text { been touched, and the } \\
\text { Unseen has been seen, } \\
\text { and the Son of the Liv- } \\
\text { ing God truly became } \\
\text { the Son of Man }\end{array}$ \\
\hline 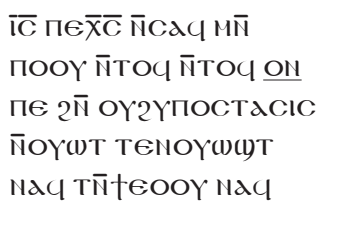 & 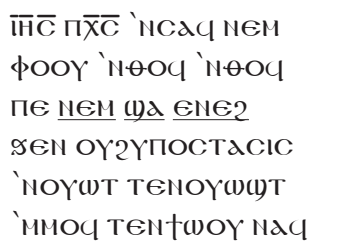 & $\begin{array}{l}\text { Jesus Christ the same } \\
\text { yesterday today and } \\
\text { forever, in one hypos- } \\
\text { tasis, we worship and } \\
\text { glorify Him. }\end{array}$ \\
\hline
\end{tabular}

\section{Commentary}

- The translation provided here is based mainly on the Bohairic text.

- We find some minor changes such as in stanza 3 смоу "sing" Sahidic and "2wc" "praise" Bohairic. And also in Stanza 4 we find in Sahaidic aсхідрхн while in Bohairic асергнтс. the same could be

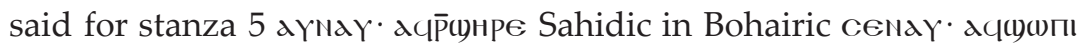
'м(у)ні

- Change in the formulation however the meaning is the same as in Stanza 2 пеноүха in Shaidic while in Bohairic фнете фшм 'ноүхал

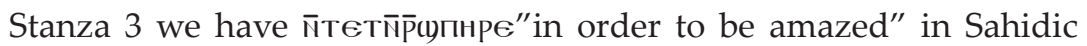
while in Boharic aрı(уфнрі "Be amazed 
- Change Coptic word into Greek as Stanza 4 aсаүzגмe - патхро-

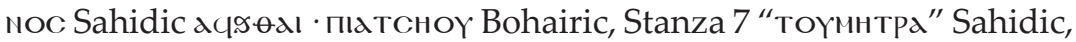
"тенехı" Bohairic, "пкд2" Sahidic, "пикосмос" Bohairic.

- Change of the person such as in stanza 1 "nan" to us" Sahidic "нwоү" to them. It is important to mention that the beginning of the stanza is addressed to the Nations.

- Addition of words such as "itaq "His" in stanza 2, Bohairic, Stanza 1 кגıд2H "from the womb" Sahidic, Stanza 6 "Or".

- Addition of a sentence, as in stanza 6 in Bohairic nем (1)d єен?

\section{Theotokia of Thursday}

Only three parts, out of nine, have their counterpart in the book of the Sahidic Antiphonarion

\begin{tabular}{|l|l|}
\hline Antiphonarion $^{93}$ & Theotokia of Thursday (part 1) \\
\hline Antiphonarion $^{94}$ & Theotokia ofThursday (part 2) \\
\hline Antiphonarion $^{95}$ & Theotokia of Thursday (part 3) \\
\hline Antiphonarion $^{96}$ & Theotokia of thursday (part 9) \\
\hline
\end{tabular}

\section{Theotokia of Friday}

The whole theotokia of Friday, including the lobsh can be found in the Sahidic book of the Anitphonarion

\begin{tabular}{|l|l|}
\hline Antiphonarion $^{97}$ & Theotokia of friday (part 1) \\
\hline Antiphonarion $^{98}$ & Theotokia of friday (part 2) \\
\hline Antiphonarion $^{99}$ & Theotokia of friday (part 3) \\
\hline Antiphonarion $^{100}$ & Theotokia of friday (part 4) \\
\hline
\end{tabular}

(92) Cramer, Krause, Das koptische Antiphonar..., 204, N 191.

(93) Ibid., 206, N 193.

(94) Ibid., 200, N 187

(95) Ibid., 210, N 203.

(96) Ibid., 216, N 213.

(97) Ibid., N 214.

(98) Ibid., N 215.

(99) Ibid., 202, N 188. 


\begin{tabular}{|l|l|}
\hline Antiphonarion $^{101}$ & Theotokia of friday (part 5) \\
\hline Antiphonarion $^{102}$ & Theotokia of friday (part 6) \\
\hline Antiphonarion $^{103}$ & Theotokia of friday (part 7) \\
\hline Antiphonarion $^{104}$ & $\begin{array}{l}\text { Lobsh of Theotokia of Friday } \\
\text { (part 1) }\end{array}$ \\
\hline
\end{tabular}

\section{Theotokia of Saturday}

I was unable to find any text in both books resembles to each other

\section{Conclusion}

No parts from the Theotokias of Monday, Saturday came to our knowledge through the Sahdic Antiphonarion.

Only one stanza from the theotokia of Sunday, three parts from the theotokias of Tuesdays and Thursdays occur in the Sahidic Antiphonarion.

The whole theotokias of Wednesday and Friday survived in the Sahidic Antiphonarion.

The comparison between both texts shows some changes adding words or changing Greek to Coptic or vice versa. In other few occasions, we have addition of complete stanzas or part of stanzas.

It is difficult to determine which of them is the original text; however the comparison shows that Bohairic possesses more parts than the Sahidic.

We can conclude with the words of Heinzgerd Brakmann and repeated by Ugo Zanetti (both most distinguished scholars in the field of Coptic Liturgy):

"...Even the simple questions concerning the liturgy of Southern Egypt do not meet a satisfactory answer. At present, scholarly literature has very little, if anything, to offer on how services were conducted in the course of time."104

(100) Cramer, Krause, Das koptische Antiphonar..., 210, N 202.

(101) Ibid., N 201.

(102) Ibid., N 200.

(103) Ibid., 228, N 230.

(104) U. Zanetti, Liturgy in the White Monastery, in: Gawdat Gabra, Hany N. TAKLA (eds.), Christianity and Monasticism in Upper Egypt, vol. 1 (Cairo-New York, 2008) 201-210, see p. 201. 